\title{
PENGARUH PENERAPAN METODE MIND MAPPING TERHADAP HASIL BELAJAR BAHASA INDONESIA SISWA SD KELAS 3
}

\author{
Dovian Syafril Umam, Latifah Nur Ahyani \\ Fakultas Psikologi Universitas Muria Kudus \\ latifah.nur@umk.ac.id
}

\begin{abstract}
Abstrak
Hasil belajar merupakan pencapaian tujuan pendidikan pada siswa yang mengikuti proses belajar mengajar di sekolah. Hasil belajar dipengaruhi oleh dua faktor yaitu faktor internal dan eksternal. Faktor internal yaitu faktor yang berasal dari dalam diri siswa, salah satunya adalah faktor kecerdasan. Sedangkan faktor eksternal yaitu faktor yang berasal dari luar, salah satunya adalah metode belajar yang digunakam oleh siswa. Penelitian ini bertujuan untuk mengetahui pengaruh penerapan metode Mind Mapping terhadap hasil belajar Bahasa Indonesia siswa SD. Subjek penelitian ini adalah siswa kelas 3 SD yang dipilih dengan metode purposive sampling. Penelitian ini menggunakan metode penelitian kuantitiatif dengan rancangan Pretest-Posttest Control Group Design. Hasil analisis menunjukkan bahwa ada perbedaan hasil belajar siswa dimana pada kelompok eksperimen yang mendapatkan perlakuan metode Mind Mapping mendapat hasil belajar yang lebih baik dibandingkan dengan kelompok kontrol yang tidak mendapatkan perlakuan diterima.
\end{abstract}

Kata Kunci : Hasil Belajar, Metode Mind Mapping

\begin{abstract}
Learning outcomes are the achievement of educational goals in students who follow the process of teaching and learning in schools. Learning outcomes are influenced by two factors: internal and external factors. Internal factors are factors that come from within students, one of which is the factor of intelligence. While external factors are factors that come from outside, one of them is the method of learning that digunakam by students. This study aims to determine the effect of Mind Mapping method on learning outcomes of Indonesian elementary students. The subject of this research is the 3rd grade of elementary school selected by purposive sampling method. This research uses quantitative research method with Pretest-Posttest Control Group Design design. The result of the analysis showed that there were differences of the students' learning outcomes which in the experimental group who received Mind Mapping method got better learning result compared to the control group that did not get the treatment accepted.
\end{abstract}

Keyword : Learning Achievement, Mind Mapping Methode 


\section{PENDAHULUAN}

Dalam dunia pendidikan terdapat berbagai macam jenis mata pelajaran yang harus ditempuh oleh peserta didik, salah satu mata pelajaran tersebut adalah mata pelajaran Bahasa Indonesia. Diadakannya mata pelajaran Bahasa Indonesia memiliki tujuan khusus, tujuan itu antara lain agar siswa memiliki kemampuan di antaranya: (1) berkomunikasi secara efektif dan efisien sesuai dengan etika yang berlaku, baik secara lisan maupun tulis, (2) menghargai dan bangga dalam menggunakan Bahasa Indonesia sebagai bahasa persatuan dan bahasa negara, (3) memahami Bahasa Indonesia dan menggunakannya dengan tepat dan kreatif untuk berbagai tujuan, (4) menggunakan Bahasa Indonesia untuk meningkatkan kemampuan intelektual serta kematangan emosional dan sosial, (5) menikmati dan memanfaatkan karya sastra untuk memperluas wawasan, memperhalus budi pekerti, serta meningkatkan pengetahuan dan kemampuan berbahasa, dan (6) menghargai dan membanggakan sastra Indonesia sebagai khasanah budaya dan intelektual manusia Indonesia (BSNP, 2006).

Berdasarkan tujuan yang telah dikemukakan ada hal yang penting guna mencapai tujuan pendidikan tersebut yaitu hasil belajar. Purwanto (2014) mengatakan bahwa hasil belajar merupakan pencapaian tujuan pendidikan pada siswa yang mengikuti proses belajar mengajar. Kemudian Gagne, Briggs dan Wager (dalam Rusmono, 2012) menyatakan bahwa kemampuan baru yang diperoleh setelah siswa belajar adalah kapabilitas atau penampilan yang dapat diamati sebagai hasil belajar. Abdurrahman (Jihad, 2012) mengatakan bahwa hasil belajar adalah kemampuan yang diperoleh anak setelah melalui kegiatan belajar.

Hasil belajar siswa yang baik atau diatas KKM bisa langsung melanjutkan ke Kompetensi Dasar selanjutnya, sedangkan hasil belajar siswa yang kurang baik atau di bawah KKM akan menyebabkan siswa tersebut belum bisa melanjutkan ke Kompetensi Dasar selanjutnya sebelum adanya perbaikan. Berdasarkan observasi pada tanggal 4 Desember ditemukan bahwa rata-rata ketuntasan hasil belajar Bahasa Indonesia kelas 3 secara klasikal sebesar $41,67 \%$. Hal ini menunjukkan bahwa hasil belajar siswa kelas 3 rendah serta Kompetensi Dasar yang diberikan tidak tuntas, sehingga siswa belum bisa melanjutkan ke Kompetensi Dasar selanjutnya. Sesuai dengan BSNP (2006) dinyatakan bahwa ketuntasan belajar setiap indikator yang telah ditetapkan dalam suatu Kompetensi Dasar berkisar antara $0-100 \%$. Namun, kriteria ideal ketuntasan untuk masing-masing indikator $75 \%$. Sementara dari segi hasil, proses dalam pembelajaraan dikatakan berhasil apabila terjadi perubahan perilaku yang positif pada diri siswa seluruhnya atau setidaknya $\geq 75 \%$.

Hasil belajar dipengaruhi oleh dua faktor. Hamdani (2011) mengungkapkan bahwa faktor-faktor yang mempengaruhi hasil belajar dapat digolongkan menjadi dua bagian, yaitu faktor dari dalam (internal) dan faktor dari luar (eksternal). Faktor dari dalam (internal) dapat 
berupa kecerdasan (intelegensi). Kartono (dalam Handani, 2011) mengemukakan bahwa kecerdasan salah satu aspek yang penting dan sangat menentukan berhasil tidaknya studi seseorang. Faktor dari luar (Eksternal) dapat berupa keadaan sekolah dimana meliputi cara memilih metode pembelajaran yang sesuai untuk siswa.

Berdasarkan uraian tentang faktor di atas dijelaskan bahwa terdapat dua bagian faktor yaitu faktor internal (dalam) dan daktor eksternal (luar). Faktor internal sangat berhubungan dengan peserta didik atau subjek di mana dalam penelitian ini mengambil peserta didik atau subjek SD kelas 3 karena Ahmadi dan Sholeh (2005) mengemukakan bahwa pikiran anak usia SD ini, berkembang secara berangsur-angsur, dan tenang. Ingatan anak usia 8-12 tahun intensitas paling besar dan kuat. Daya menghafal dan daya kosentrasi adalah paling kuat. Anak pun mampu memuat jumlah materi ingatan paling banyak. Berdasarkan penjelasan di atas metode Mind Mapping sangat tepat dikarenakan Mind Mapping akan membantu siswa untuk berkonsentrasi, mengingat lebih baik, dan belajar lebih cepat (Buzan, 2012).

Berdasarkan BSNP (2006) anak kelas 3 SD diharuskan memiliki kompetensi dasar antara lain mampu menceritakan isi teks, menceritakan kembali isi dongeng dengan demikian Mind Mapping tepat untuk mereka karena menurut Porter, Reardon, \& Nourie (2010) Mind Mapping (peta pikiran) bisa juga digunakan untuk tugas membaca, curah-gagasan (brainstorming), serta menulis. Dimana ketika dalam tugas curah-gagasan ada satu siswa yang meneriakkan gagasan dan siswa yang lain merekam informasi yang diberikan serta yang lain melanjutkan diskusi, Mind Mapping dibuat agar sesuai dengan lompatan yang terjadi di dalam otak karena peta pikiran bekerja seperti otak.

Hudoyo (dalam Suprihatiningrum, 2013) mengemukakan bahwa metode pembelajaran merupakan suatu cara atau teknik mengajar topik-topik tertentu yang disusun secara teratur dan logis. Salah satu metode pembelajaran yang baik dan dapat meningkatkan hasil belajar adalah metode Mind Mapping. Karena Mind Mapping membantu siswa belajar lebih cepat dan efisien (Buzan, 2008). Selain itu Mind Mapping juga membuat keseimbangan kinerja dari otak kanan dan otak kiri seperti pendapat yang diungkapkan oleh Windura (2008) bahwa Mind Mapping membantu penggunaan kedua belah otak secara seimbang.

Menurut Buzan (2012) mengemukakan bahwa ada tujuh langkah dalam membuat Mind Mapping, yaitu:

a. mulailah dari bagian tengah kertas kosong yang sisi panjangnya diletakkan mendatar;

b. gunakan gambar atau foto untuk ide sentral;

c. gunakan warna;

d. hubungkan cabang-cabang utama ke gambar pusat dan hubungkan cabang-cabang tingkat dua dan tiga ke tingkat satu dan dua, dan seterusnya;

e. buatlah garis hubung yang melengkung, bukan garis yang lurus;

f. gunakan satu kata kunci untuk setiap garis; dan 
g. gunakan gambar.

Selain hal tersebut Mind Mapping tepat untuk pembelajaran Bahasa Indonesia karena terdapat aspek-aspek dalam bahasa Indonesia yang harus dikuasai oleh peserta didik antara lain menurut BSNP (2006) meliputi empat aspek atau ruang lingkup, yaitu (1) mendengarkan (2) berbicara (3) membaca (4) menulis, selaras dengan hal tersebut maka metode Mind Mapping sangat cocok untuk pebelajaran Mind Mapping di mana Mind Mapping (peta pikiran) bisa juga digunakan untuk tugas membaca, curah-gagasan (brainstorming), serta menulis (Porter, Reardon, \& Nourie, 2010).

Berdasarkan teori di atas dapat disimpulkan bahwa seseorang yang belajar dengan menggunakan metode yang baik untuk meningkatkan daya ingat dan pemahaman seperti Mind Mapping karena Mind Mapping merupakan metode pembelajaran sangat baik digunakan oleh guru untuk meningkatkan daya hafal siswa dan pemahaman konsep siswa yang kuat (Sugiarto 2004). Maka hasil belajarnya akan meningkat juga pada pembelajaran yang mengutamakan hafalan (daya ingat) dan pemahaman.

Penjelasan yang telah disampaikan di atas didukung dengan penelitian yang dilakukan oleh Widiari, dkk dengan judul "Pengaruh Metode Pembelajaran Mind Mapping dan Ekspositori Terhadap Hasil Belajar Matematika di SD Gugus IX Kecamatan Buleleng" menunjukkan bahwa siswa yang diberikan pembelajaran dengan metode Mind Mapping memiliki hasil belajar yang tinggi dengan rata-rata skor 42,10 dibandingkan dengan teknik Ekspositori yang menunjukkan skor rata-rata 32,64.

Penelitian lain yang dilakukan oleh Silaban, dkk (2012) yang berjudul "Pengaruh Media Mind Mapping Terhadap Kreativitas dan Hasil Belajar Kimia Siswa SMA pada Pembelajaran Menggunakan Advance Organizer". Menunjukkan bahwa kelompok eksperimen 1 menunjukkan peningkatan hasil belajar sebesar 68\%. Ini menunjukkan bahwa Mind Mapping terbukti bisa untuk meningkatkan hasil belajar siswa. Buzan (2008) mengemukakan bahwa Mind Mapping adalah cara termudah menempatkan informasi ke dalam otak dan mengambil informasi ke luar dari otak.

Penelitian eksperimen ini bertujuan untuk mengetahui pengaruh penerapan metode Mind Mapping terhadap hasil belajar Bahasa Indonesia siswa SD kelas 3. Metode Mind Mapping ini baik digunakan oleh guru dalam melakukan kegiatan belajar mengajar. Sebagaimana pendapat yang diungkapkan oleh Sugiarto (2004) bahwa Mind Mapping merupakan metode pembelajaran sangat baik digunakan oleh guru untuk meningkatkan daya hafal siswa dan pemahaman konsep siswa yang kuat, siswa juga dapat meningkatkan daya kreativitas melalui kebebasan berimajinasi. Silberman (2006) juga mengungkapkan bahwa Mind Mapping merupakan cara kreatif bagi tiap siswa untuk menghasilkan gagasan, mencatat apa yang dipelajari, atau merencanakan tugas baru. 


\section{METODE PENELITIAN}

\section{Subjek penelitian}

Subjek penelitian dalam penelitian ini adalah siswa SD 2 JOJO kelas 3 dipilih menjadi kelompok eksperimen, kemudian SD 3 JOJO kelas 3 dipilih sebagai kelompok kontrol. SD 2 JOJO dan SD 3 JOJO dipilih dalam penelitian ini karena SD 2 JOJO dan SD 3 JOJO berada pada daerah yang sama dengan kurikulum sama selain itu karena berada didaerah yang sama maka karakteristik siswanya tidak jauh berbeda. Sampel penelitian ini diambil menggunakan teknik purposive sampling.

\section{Identifikasi Variabel Penelitian}

Variabel tergantung pada penelitian adalah hasil belajar siswa. Hasil belajar adalah pencapaian atau hasil yang telah didapatkan oleh siswa dapat berupa nilai yang telah dikategorikan serta setelah siswa mengikuti kegiatan belajar mengajar selama kurun waktu tertentu yang telah ditentukan oleh satuan pendidikan.

Hasil belajar dalam penelitian ini diukur dengan menggunakan sederetan pertanyaan atau tes. Arikunto (2010) mengemukakan bahwa tes adalah serentetan pertanyaan atau latihan serta alat lain yang digunakan untuk mengukur keterampilan, pengetahuan intelegensi, kemampuan atau bakat yang dimiliki oleh individu atau kelompok.

Variabel bebas pada penelitian ini adalah metode mind mapping. Metode Mind Mapping adalah suatu metode menekankan pada keseimbangan otak kanan dan otak kiri dengan menggabungkan berbagai gambar, warna, dan bentuk ke dalam sebuah catatan materi sehingga otak akan lebih mudah mengingatnya.

\section{Instrumen penelitian}

\section{Intrumen Pengukuran Hasil Belajar Siswa}

Dalam penelitian ini hasil belajar diukur dengan menggunakan 2 macam instrumen hasil belajar yaitu instrumen yang berupa tes dan juga berupa rating scale, instrumen ini disusun berdasarkan ranah-ranah hasil belajar menurut Bloom (Hamdani, 2011) menyebutkan bahwa hasil belajar dibedakan menjadi tiga ranah, yaitu kognitif, afektif, dan psikomotor. Instrumen yang berupa serentetan pertanyaan atau tes digunakan untuk mengukur ranah kognitif. Menurut Arikunto (2010) mengemukakan bahwa tes adalah serentetan pertanyaan atau latihan serta alat lain yang digunakan untuk mengukur keterampilan, pengetahuan intelegensi, kemampuan atau bakat yang dimiliki oleh individu atau kelompok.

Instrumen yang berupa rating scale digunakan untuk mengukur ranah afektif dan psikomotor. Ranah afektif memiliki aspek menurut Siregar (2011) menjelaskan bahwa ranah 
afektif terdiri dari Penerimaan (receiving), Pemberian respon (responding), Pemberian nilai atau penghargaan (valuing), Pengorganisasian (organization), Karakterisasi (characterization) Ranah psikomotor memiliki aspek menurut Purwanto (2014) mengklasifikan hasil belajar psikomotor menjadi enam, yaitu persepsi, kesiapan, gerakan terbimbing, gerakan terbiasa, gerakan komplek, dan kreativitas.

Tabel 1

Blue Print Rating Scale Hasil Belajar

\begin{tabular}{|c|l|c|c|}
\hline Ranah & \multicolumn{1}{|c|}{ Aspek } & No.Item & Jumlah \\
\hline \multirow{4}{*}{ Afektif } & Penerimaan & $1,2,3$ & $\mathbf{3}$ \\
\cline { 2 - 4 } & Respon & 4.5 .6 & $\mathbf{3}$ \\
\cline { 2 - 4 } & Pemberian nilai & $7,8,9$ & $\mathbf{3}$ \\
\cline { 2 - 4 } & Pengorganisasian & $10,11,12$ & $\mathbf{3}$ \\
\cline { 2 - 4 } & Karakteristik & $13,14,15$ & $\mathbf{3}$ \\
\hline \multirow{5}{*}{ Psikomotor } & $16,17,18$ & $\mathbf{3}$ \\
\cline { 2 - 4 } & Persepsi & $19,20,21$ & $\mathbf{3}$ \\
\cline { 2 - 4 } & Kesiapan & $22,23,24$ & $\mathbf{3}$ \\
\cline { 2 - 4 } & Gerakan terbimbing & $25,26,27$ & $\mathbf{3}$ \\
\cline { 2 - 4 } & Gerakan terbiasa & $28,29,30$ & $\mathbf{3}$ \\
\cline { 2 - 4 } & Gerakan kompleks & $31,32,33$ & $\mathbf{3 3}$ \\
\cline { 2 - 4 } & Kreatifitas & $\mathbf{3 3}$ & \\
\hline
\end{tabular}

\section{Metode Pembelajaran Mind Mapping dalam Meningkatkan Hasil Belajar Siswa}

Perlakuan yang diberikan dalam penelitian ini adalah sebuah metode pembelajaran Mind Mapping. Metode yang dirancang dan dipopulerkan oleh Tony Buzan bagi siswa untuk mampu meningkatkan hasil belajar siswa yang bersangkutan. Dalam metode Pembelajaran Mind Mapping ini siswa diajak untuk melakukan cara mencatat suatu materi menggunakan metode Mind Mapping yang dirancang oleh peneliti kemudian diarahkan oleh asisten penelitian. Langkah-langkah yang digunakan dalam membuat Mind Mapping menurut Buzan (2012) bahwa ada tujuh langkah dalam membuat Mind Mapping, yaitu: 1) mulailah dari bagian tengah kertas kosong yang sisi panjangnya diletakkan mendatar; 2) gunakan gambar atau foto untuk ide sentral; 3) gunakan warna; 4) hubungkan cabang-cabang utama ke gambar pusat dan hubungkan cabang-cabang tingkat dua dan tiga ke tingkat satu dan dua, dan seterusnya; 5) buatlah garis hubung yang melengkung; 6) gunakan satu kata kunci untuk setiap haris; dan 7) gunakan gambar. Penerapan metode Mind Mapping ini dilakukan sebanyak 10 keli pertemuan, satu kali pertemuan membutuhkan waktu selama 60 menit.

Rancangan penelitian dalam penelitian ini menggunakan rancangan Pretest-Posttest Control Group Design (Seniati dkk, 2005). Desain ini merupakan desain dua kelompok, dua kelompok yang diamati yang terdiri dari kelompok eksperimen dan kelompok control. Pada 
desain ini pengukuran dilakukan dua kali yaitu sebelum diberikan perlakuan (pretest) dan sesudah diberikan perlakuan (posttest).

Desain Rancangan Eksperimen

$\begin{array}{llll}\mathrm{KE} & \mathrm{O}_{1} \longrightarrow \mathrm{X} \longrightarrow \mathrm{O}_{2} \\ \mathrm{KK} & \mathrm{O}_{1} \longrightarrow \mathrm{O}_{2}\end{array}$

Keterangan :

KE : Kelompok Eksperimen

KK : Kelompok Kontrol

O1 : Pre-test Hasil Belajar

X : Perlakuan Mind Mapping

O2 : Post-test Hasil Belajar

\section{HASIL DAN PEMBAHASAN}

\section{Deskripsi Data Penelitian}

Tabel 2 statistik deskriptif hasil belajar siswa menunjukkan bahwa terjadi penurunan hasil belajar siswa pada kelompok kontrol serta terjadi peningkatan hasil belajar siswa pada kelompok eksperimen. Penurunan hasil belajar pada kelompok kontrol diketahui dari mean Pretest kognitif 51,25 dengan standart deviasi 13,164 menjadi mean posttest kognitif 49,17 dengan standart deviasi 17,688, dan juga mean Pretest afektif 64,25 dengan standart deviasi 16,125 menjadi mean posttest afektif 62,08 dengan standart deviasi 17,000 begitu pula kelompok eksperimen dapat diketahui dari perbedaan mean dari pretest dan posttest dimana mean pretetst kognitif 54,17 dengan standart deviasi 14,434 menjadi mean posttest kognitif 78,33 dengan standart deviasi 12,492, begitu pula mean pretest afektif 64,33 dengan standart deviasi 17,127 menjadi mean posttest afektif 87,00 dengan standart deviasi 17,909.

Tabel 2

Statistik Deskriptif Hasil Belajar Siswa

\begin{tabular}{|l|l|l|l|l|l|}
\hline \multirow{2}{*}{ Kelompok } & \multicolumn{1}{l|}{ Pre Post } & Mean & SD & Min & Mak \\
\cline { 2 - 6 } & Pretest Kog & 51,25 & 13,164 & 25 & 70 \\
\cline { 2 - 6 } Kontrol & Posttest Kog & 49,17 & 17,688 & 20 & 75 \\
\cline { 2 - 6 } & Pretest Aff & 64,25 & 16,125 & 49 & 85 \\
\cline { 2 - 6 } & Posttest Aff & 62,08 & 17.000 & 48 & 86 \\
\hline \multirow{3}{*}{ Eksperimen } & Pretest Kog & 54,17 & 14,434 & 20 & 70 \\
\cline { 2 - 6 } & Posttest Kog & 78,33 & 12,492 & 55 & 95 \\
\cline { 2 - 6 } & Pretest Aff & 64,33 & 17,127 & 48 & 86 \\
\hline
\end{tabular}




\begin{tabular}{|l|l|l|l|l|l|}
\hline & Posttest Aff & 87,00 & 17,909 & 71 & 109 \\
\hline
\end{tabular}

\section{Deskripsi Kategori Hasil Belajar Siswa}

Hasil pengukuran hasil belajar siswa atau skor yang diperoleh siswa dikelompokkan berdasarkan kategorisasi hasil belajar siswa. Kategorisasi ini bertujuan untuk menempatkan individu kepada kelompok-kelompok yang sesuai dengan hasil yang mereka miliki. Menurut Azwar (2003), dasar dari pembuatan kategorisasi adalah asumsi bahwa skor terdistribusi secara normal.

Kategorisasi ini menggunakan tiga kategori, kategori itu adalah tinggi, sedang, rendah. Diketahui batasan kategori dengan rumus pada tabel berikut ini :

Tabel 3

Kategorisasi Hasil Belajar Siswa

\begin{tabular}{|c|c|}
\hline Kategori & Norma \\
\hline Tinggi & $\mathrm{X}>+\mathrm{M} 1 \mathrm{SD}$ \\
\hline Sedang & $\mathrm{M}-1 \mathrm{SD}<\mathrm{X} \leq+1 \mathrm{SD}$ \\
\hline Rendah & $\mathrm{X} \leq \mathrm{M}-1 \mathrm{SD}$ \\
\hline
\end{tabular}

Kategori hasil belajar siswa pada kelompok kontrol dan eksperimen pada saat pretest ditentukan dari hasil pretest yang telah didapat yang menggunakan instrumen pengukuran hasil belajar, dimana dalam pretest tersebut kelompok kontrol mendapatkan mean kognitif sebesar 51,25 dan standart deviasi 13,164, serta mean afektif sebesar 64,25 dan standart deviasi 16,125,sedangkan kelompok eksperimen mendapatkan mean kognitif sebesar 54,17 dan standart deviasi 14,434, kemudian mean afektif sebesar 64,33 dan standart deviasi 17,127 dari data tersebut dapat dibuat data kategorisasi hasil belajar siswa sebagai berikut :

Tabel 4

Kategorisasi Hasil Belajar Siswa Pada Pretest Kelompok Kontrol Kognitif

\begin{tabular}{|c|c|c|}
\hline ALAT UKUR & RENTANG NILAI & KATEGORI \\
\hline \multirow{2}{*}{$\begin{array}{c}\text { Instrumen Hasil Belajar } \\
\text { Siswa }\end{array}$} & $\mathrm{X}>64,414$ & Tinggi \\
\cline { 2 - 3 } & $38,068<\mathrm{X} \leq 64,414$ & Sedang \\
\cline { 2 - 3 } & $\mathrm{X}<38,068$ & Rendah \\
\hline
\end{tabular}

Tabel 5

Kategorisasi Hasil Belajar Siswa Pada Pretest Kelompok Kontrol Afektif

\begin{tabular}{|c|c|c|}
\hline ALAT UKUR & RENTANG NILAI & KATEGORI \\
\hline \multirow{2}{*}{$\begin{array}{c}\text { Instrumen Hasil Belajar } \\
\text { Siswa }\end{array}$} & $\mathrm{X}>80,375$ & Tinggi \\
\cline { 2 - 3 } & $48,125<\mathrm{X} \leq 80,375$ & Sedang \\
\cline { 2 - 3 } & $\mathrm{X}<48,125$ & Rendah \\
\hline
\end{tabular}


Tabel 6

Kategorisasi Hasil Belajar Siswa Pada Pretest Kelompok Eksperimen Kognitif

\begin{tabular}{|c|c|c|}
\hline ALAT UKUR & RENTANG NILAI & KATEGORI \\
\hline \multirow{2}{*}{$\begin{array}{c}\text { Instrumen Hasil Belajar } \\
\text { Siswa }\end{array}$} & $\mathrm{X}>68,604$ & Tinggi \\
\cline { 2 - 3 } & $39,736<\mathrm{X} \leq 68,604$ & Sedang \\
\cline { 2 - 3 } & $\mathrm{X}<39,736$ & Rendah \\
\hline
\end{tabular}

Tabel 7

Kategorisasi Hasil Belajar Siswa Pada Pretest Kelompok Eksperimen Afektif

\begin{tabular}{|c|c|c|}
\hline ALAT UKUR & RENTANG NILAI & KATEGORI \\
\hline \multirow{2}{*}{$\begin{array}{c}\text { Instrumen Hasil Belajar } \\
\text { Siswa }\end{array}$} & $X>81,457$ & Tinggi \\
\cline { 2 - 3 } & $47,203<X \leq 81,457$ & Sedang \\
\cline { 2 - 3 } & $X<47,203$ & Rendah \\
\hline
\end{tabular}

Berdasarkan pengelompokkan kategorisasi hasil belajar siswa pretest diketahui siswasiswa pada kelompok kontrol dengan kategori yang tinggi sebanyak tiga siswa, sedang sebanyak tujuh siswa, dan rendah sebanyak dua siswa pada kognitif, sedangkan pada afektif kategori yang tinggi sebanyak lima siswa, sedang sebanyak tujuh siswa, dan tidak ada siswa yang tergolong rendah. Serta diketahui juga siswa-siswa pada kelompok eksperimen dengan kategori yang tinggi sebanyak dua siswa, sedang sebanyak sembilan siswa, dan rendah sebanyak satu siswa pada kognitif, sedangkan pada afektif kategori yang tinggi sebanyak lima siswa, sedang sebanyak tujuh siswa, dan tidak ada siswa yang tergolong rendah.

Tabel 8

Jumlah Siswa Berdasarkan Kategorisasi Hasil Belajar Siswa Saat Pretest Pada Kelompok Kontrol Dan Eksperimen.

\begin{tabular}{|c|c|c|c|c|c|}
\hline Kelompok & Kog/Aff & Tinggi & Sedang & Rendah & Jumlah \\
\hline \multirow{2}{*}{ Kontrol } & Kognitif & 3 & 7 & 2 & 12 \\
\cline { 2 - 6 } & Affektif & 5 & 7 & 0 & 12 \\
\hline \multirow{2}{*}{ Eksperimen } & Kognitif & 2 & 9 & 1 & 12 \\
\cline { 2 - 6 } & Affektif & 5 & 7 & 0 & 12 \\
\hline
\end{tabular}

Kategori hasil belajar siswa pada kelompok kontrol dan eksperimen pada saat posttest juga sama ditentukan dari hasil post-test yang telah didapat yang menggunakan instrumen pengukuran hasil belajar, dimana dalam post-test tersebut kelompok kontrol mendapatkan mean kognitif sebesar 49,17 dan standart deviasi 17,688, dan mendapatkan mean afektif sebesar 62,08 dan standart deviasi 17.000 sedangkan kelompok eksperimen mendapatkan mean kognitif sebesar 78,33 dan standart deviasi 12,492, dan mendapatkan 
mean afektif sebesar 87,00 dan standart deviasi 17,909 dari data tersebut dapat dibuat data kategorisasi hasil belajar siswa sebagai berikut:

Tabel 9

Kategorisasi Hasil Belajar Siswa Pada Post-test Kognitif Kelompok Kontrol

\begin{tabular}{|c|c|c|}
\hline ALAT UKUR & RENTANG NILAI & KATEGORI \\
\hline \multirow{2}{*}{$\begin{array}{c}\text { Instrumen Hasil Belajar } \\
\text { Siswa }\end{array}$} & $\mathrm{X}>66,858$ & Tinggi \\
\cline { 2 - 3 } & $31,482<\mathrm{X} \leq 66,858$ & Sedang \\
\cline { 2 - 3 } & $\mathrm{X}<31,482$ & Rendah \\
\hline
\end{tabular}

Tabel 10

Kategorisasi Hasil Belajar Siswa Pada Post-test Afektif Kelompok Kontrol

\begin{tabular}{|c|c|c|}
\hline ALAT UKUR & RENTANG NILAI & KATEGORI \\
\hline \multirow{2}{*}{$\begin{array}{c}\text { Instrumen Hasil Belajar } \\
\text { Siswa }\end{array}$} & $\mathrm{X}>79,08$ & Tinggi \\
\cline { 2 - 3 } & $45,08<\mathrm{X} \leq 79,09$ & Sedang \\
\cline { 2 - 3 } & $\mathrm{X}<45,08$ & Rendah \\
\hline
\end{tabular}

Tabel 11

Kategorisasi Hasil Belajar Siswa Pada Post-test Kognitif Kelompok Eskperimen

\begin{tabular}{|c|c|c|}
\hline ALAT UKUR & RENTANG NILAI & KATEGORI \\
\hline \multirow{2}{*}{$\begin{array}{c}\text { Instrumen Hasil Belajar } \\
\text { Siswa }\end{array}$} & $\mathrm{X}>90,822$ & Tinggi \\
\cline { 2 - 3 } & $65,838<\mathrm{X} \leq 90,822$ & Sedang \\
\cline { 2 - 3 } & $\mathrm{X}<65,838$ & Rendah \\
\hline
\end{tabular}

Tabel 12

Kategorisasi Hasil Belajar Siswa Pada Post-test Afektif Kelompok Eskperimen

\begin{tabular}{|c|c|c|}
\hline ALAT UKUR & RENTANG NILAI & KATEGORI \\
\hline \multirow{2}{*}{$\begin{array}{c}\text { Instrumen Hasil Belajar } \\
\text { Siswa }\end{array}$} & $\mathrm{X}>104,909$ & Tinggi \\
\cline { 2 - 3 } & $69,091<\mathrm{X} \leq 104,909$ & Sedang \\
\cline { 2 - 3 } & $\mathrm{X}<69,091$ & Rendah \\
\hline
\end{tabular}

Berdasarkan pengelompokkan kategorisasi hasil belajar siswa post-test diketahui siswa-siswa pada kelompok kontrol dengan kategori yang tinggi sebanyak tiga siswa, sedang sebanyak tujuh siswa, dan rendah sebanyak dua siswa pada kognitif, sedangkan pada afektif kategori yang tinggi sebanyak empat siswa, sedang sebanyak delapan siswa, dan tidak ada siswa yang tergolong rendah. Serta diketahui juga siswa-siswa pada kelompok eksperimen dengan kategori yang tinggi sebanyak dua siswa, sedang sebanyak delapan siswa, dan rendah sebanyak dua siswa pada kognitif, sedangkan pada afektif kategori yang tinggi sebanyak lima siswa, sedang sebanyak tujuh siswa, dan tidak ada siswa yang tergolong rendah. 
Tabel 13

Jumlah Siswa Berdasarkan Kategorisasi Hasil Belajar Siswa Saat Post-test Pada Kelompok Kontrol Dan Eksperimen.

\begin{tabular}{|c|c|c|c|c|c|}
\hline Kelompok & Kog/Af & Tinggi & Sedang & Rendah & Jumlah \\
\hline \multirow{2}{*}{ Kontrol } & Kognitif & 3 & 7 & 2 & 12 \\
\cline { 2 - 6 } & Afektif & 4 & 8 & 0 & 12 \\
\hline \multirow{2}{*}{ Eksperimen } & Kognitif & 2 & 8 & 2 & 12 \\
\cline { 2 - 6 } & Afektif & 5 & 7 & 0 & 12 \\
\hline
\end{tabular}

3. Uji Prasyarat

a) Uji Normalitas

Uji normalitas dilakukan untuk mengetahui data bersifat normal atau tidak. Hasil uji normalitas variabel hasil belajar siswa menunjukkan bahwa empat kelompok data tersebut adalah normal dengan $p$ kognitif sebesar 0,652 $(p>0,05)$ dan $p$ afektif sebesar $0,123(p>$ $0,05)$ untuk data pretest dan $p$ kognitif sebesar $0,849(p>0,05)$ dan $p$ afektif sebesar 0,075 ( $p>0,05)$ untuk data post-test pada kelompok kontrol, sedangkan untuk kelompok eksperimen memiliki nilai $p$ kognitif sebesar 0,493 $(p>0,05)$ dan $p$ afektif sebesar 0,148 ( $p>$ $0,05)$ untuk data pretest dan $p$ kognitif sebesar 0,902 $(p>0,05)$ dan $p$ afektif sebesar 0,142 $(p>0,05)$ untuk data post-test.

Tabel 14

Hasil Uji Normalisasi Variabel Hasil Belajar

\begin{tabular}{|c|l|c|c|c|}
\hline \multirow{2}{*}{ Kelompok } & Pre & $\begin{array}{c}\text { Kolmogrov - } \\
\text { Sminorov Z }\end{array}$ & Post & Keterangan \\
\hline \multirow{4}{*}{ Kontrol } & Pre-test Kog & 0,735 & 0,652 & Normal \\
\cline { 2 - 5 } & Pre-test Aff & 1,180 & 0,123 & Normal \\
\cline { 2 - 5 } & Post-test Kog & 0,611 & 0,849 & Normal \\
\cline { 2 - 5 } & Post-test Aff & 1,282 & 0,075 & Normal \\
\hline \multirow{4}{*}{ Eksperimen } & Pre-test Kog & 0,832 & 0,493 & Normal \\
\cline { 2 - 5 } & Pre-test Aff & 1,141 & 0,148 & Normal \\
\cline { 2 - 5 } & Post-test Kog & 0,569 & 0,902 & Normal \\
\cline { 2 - 5 } & Post-test aff & 1,150 & 0,142 & Normal \\
\hline
\end{tabular}

b) Uji Homogenitas

Uji homogenitas dilakukan bertujuan untuk mengethui data item-item variabel mempunyai sifat homogen atau tidak, uji homogenitas variabel hasil belajar siswa menunjukkan $F$ kognitif sebesar 0,267 dengan $p$ kognitif sebesar 0,610 ( $p>0,05)$, kemudian $F$ afektif sebesar 0,00 dengan $p$ afektif sebesar $0,990(p>0,05)$. Dari hasil tersebut maka dapat dinyatakan bahwa item-item dari variabel hasil belajar mempunyai sifat homogen. 
c) Uji Hipotesis

Berdasarkan uji hipotesis diketahui bahwa hipotesis pertama yang menyatakan ada perbedaan hasil belajar siswa antara sebelum diberikan perlakuan metode Mind Mapping dengan sesudah diberikan perlakuan metode Mind Mapping pada kelompok eksperimen diterima. Hal ini dibuktikan dengan melihat hasil uji perbedaan pretest-posttest kelompok eksperimen dimana diperoleh besarnya koefisien beda dengan $t$ kognitif sebesar - 11,415 dengan $p$ sebesar $0,000(p<0,01)$, serta t afektif sebesar $-33,435$ dengan $p$ sebesar 0,00 $(p<0,01)$.

Hipotesis kedua yang menyatakan bahwa ada perbedaan hasil belajar siswa dimana pada kelompok eksperimen yang mendapatkan perlakuan metode Mind Mapping mendapat hasil belajar yang lebih baik dibandingkan dengan kelompok kontrol yang tidak mendapatkan perlakuan diterima. Hal ini dibuktikan dengan dimana kelompok eksperimen dan kontrol mendapatkan koefisien beda $t$ kognitif sebesar 4,666 dengan $p$ sebesar $0,000(p<0,01)$, sedangkan $t$ afektif sebesar 3,496 dengan $p$ sebesar $0,002(p<0,01)$, dan mean kognitif kelompok eksperimen sebesar 78,33 dan mean kognitif kelompok kontrol sebesar 49,17. Sedangkan mean afektif kelompok eksperimen sebesar 87,00 dan mean afektif kelompok kontrol sebesar 62,08 . Hasil tersebut menunjukkan bahwa terdapat perbedaan hasil belajar antara kelompok kontrol dan kelompok eksperimen dimana kelompok eksperimen mendapatkan hasil belajar yang lebih tinggi dari kelompok kontrol.

Berdasarkan hasil yang telah disampaikan diatas menunjukkan bahwa terjadinya peningkatan nilai hasil belajar pada kelompok eksperimen, menunjukkan bahwa metode Mind Mapping dapat meningkatkan nilai hasil belajar siswa. Hal tersebut sesuai dengan pernyataan Suyatno (2009) bahwa untuk anak-anak, peta pikiran memiliki manfaat, yaitu membantu dalam mengingat, mendapatkan ide, menghemat waktu, berkonsentrasi, mendapatkan nilai yang lebih bagus, mengatur pikiran dan hobi, media bermain, bersenang-senang dalam menuangkan imajinasi yang tentunya memunculkan kreativitas. Selain itu dimana mata pelajaran Bahasa Indonesia yang memiliki bacaan yang panjang juga sangat cocok untuk metode Mind Mapping dimana menurut Buzan (2012) dengan Mind Mapping, daftar informasi yang panjang bisa dialihkan menjadi diagram warna-warni, sangat teratur, dan mudah diingat yang bekerja selaras dengan cara kerja otak alami dalam melakukan berbagai hal.

Pernyataan diatas didukung oleh penelitian yang dilakukan oleh Purwasari (2013) dengan judul "Meningkatkan Hasil Belajar IPA tentang Perubahan Kenampakan Permukaan Bumi dan Benda Langit melalui Peta Pikiran pada Anak Kesulitan Belajar Kelas IV SD 13 Balai-Balai Kota Padang Panjang" menunjukkan bahwa keberhasilan pada siklus 1 memperoleh rata-rata 5,3 atau persentase rata-rata $53 \%$. Berdasarkan taraf rata-rata baru 5,3 
masih berada pada taraf kurang atau belum berhasil, sehingga perlu dilanjutkan pada siklus berikutnya. Pada siklus 2 terjadi peningkatan persentase keberhasilan mencapai $86 \%$.

\section{SIMPULAN}

Hasil penelitian memenunjukkan ada perbedaan hasil belajar siswa dimana pada kelompok eksperimen yang mendapatkan perlakuan metode Mind Mapping mendapat hasil belajar yang lebih baik dibandingkan dengan kelompok kontrol yang tidak mendapatkan perlakuan diterima, hal tersebut dibuktikan dengan hasil uji perbedaan pretest-posttest kelompok eksperimen diperoleh besar koefisien beda dengan t kognitif sebesar - 11,415 serta t afektif sebesar - 33,435. Berdasarkan data tersebut menunjukkan bahwa terdapat perbedaan hasil belajar siswa antara sebelum dan sesudah perlakuan metode Mind Mapping pada kelompok eksperimen. 


\section{DAFTAR PUSTAKA}

Ahmadi, A., \& Sholeh, M. (2005). Psikologi Perkembangan. Jakarta: PT. Rineka Cipta.. Arikunto. (2010). Prosedur Penelitian Suatu Pendekatan Praktik. Jakarta: Rineka Cipta. Azwar, S. (2006). Penyusunan Skala Psikologi. Yogyakarta : Pustaka Belajar

Badan Standar Nasional Pendidikan. (2006). Peraturan Menteri Pendidikan Nasional Republik Indonesia No. 22 Tahun 2006 tentang Standar Isi untuk Satuan Pendidikan Dasar dan Menengah. Jakarta: Badan Standar Nasional Pendidikan.

Buzan, T. (2008). Buku Pintar Mind Map. Jakarta: PT Gramedia Pustaka Utama.

. (2012). The Ultimate Book of Mind Maps. Sydney: Harper Collins Publishers (Australia) Pty.

Porter, D., Reardon., Nourie. (2007). Quantum Teaching: Memperaktikkan Quantum Learning di Runag-ruang Kelas: Bandung: Kaifa.

Hamdani. (2011). Strategi Belajar Mengajar. Bandung: CV Pustaka Setia.

Jihad, H., dkk. (2012). Evaluasi Pembelajaran. Yogyakarta: Multi Pressindo.

Purwanto. (2014). Evaluasi Hasil Belajar. Yogyakarta: Pustaka Belajar.

Purwasari, Y. (2013). Meningkatkan Hasil Belajar IPA tentang Perubahan Kenampakan Permukaan Bumi dan Benda Langit melalui Peta Pikiran pada Anak Kesulitan Belajar Kelas IV SD 13 Balai-Balai Kota Padang Panjang. E-JUPEKHU (Jurnal Ilmiah Pendidikan Khusus).

Rusmono. (2012). Strategi Pembelajaran dengan Problem Based Learning itu Perlu: untuk Meningkatkan Profesionalitas Guru. Bogor: Ghalia Indonesia.

Seniati, dkk. (2005). Psikologi Eksperimen. Jakarta : PT. Indeksi

Silberman. (2009). Active Learning: 101 strategi pembelajaran aktif: Yogyakarta: Pustaka Intan Madani.

Silaban, dkk. (2012). Pengaruh Media Mind Mapping Terhadap Kreativitas dan Hasil Belajar Kimia Siswa SMA pada Pembelajaran Menggunakan Advance Organizer.

Siregar, N. (2011). Teori Belajar dan Pembelajaran. Bogor: Ghalia Indonesia.

Sugiarto. (2004). Mengoptimalkan Daya Kerja Otak dengan Berpikir Holistik dan Kreatif. Jakarta: Gramedia Pustaka Utama.

Suprihatiningrum. (2013). Strategi Pembelajaran. Yogyakarta: Ar-Ruzz Media.

Suyatno. (2009). Menjelajah Pembelajaran Inovatif. Surabaya: Masmedia Buana Pustaka. Windura. (2008). Mind Map Langkah Demi Langkah. Jakarta: Elex Media Komputindo 